\title{
Education 4.0: Pergeseran pendidikan sebagai konsekuensi revolusi industri 4.0
}

\author{
Elisabeth Pratidhina \\ Widya Mandala Catholic University Surabaya, Indonesia \\ Email: elisa.founda@gmail.com
}

\begin{abstract}
Abstrak
Revolusi industri 4.0 melahirkan perubahan pada cara hidup, bekerja dan berkomunikasi. Dunia pendidikan mau tidak mau harus terus berkembang untuk menyesuaikan dengan tuntutan perubahan yang terjadi di dunia saat ini. Revolusi industri 4.0 telah melahirkan pergeseran pendiidkan. Education 4.0 adalah pendekatan yang diharapkan dapat menyesuaikan pendidikan dengan kemunculan revolusi industry 4.0. Education 4.0 sebenarnya mengusung beberapa konsep yang sudah dikenal, yaitu self-directed learning dan long-life learning. Artikel ini membahas beberapa pergeseran pendidikan pada Education 4.0 dan fenomena munculnya teknologi pendidikan baru yang berusaha memenuhi kebutuhan self-directed learning dan long-life learning.
\end{abstract}

Kata Kunci: Revolusi Industri 4.0, Education 4.0, Self-Directed Learning, LongLife Learning, Teknologi Pendidikan

\begin{abstract}
Industrial Revolution 4.0 is changing how we live, work, and communicate. The education field should develop to adapt to the revolutionary changes that happen in the world recently. Industrial revolution 4.0 makes shifted paradigm in education. Education 4.0 is the desired approach to learning that aligns itself with the emerging fourth industrial
\end{abstract}


revolution. It brings up the well-known educational concepts such as self-directed learning and long-life learning. This paper discuss shifting educational theory in Education 4.0 and the phenomenon of the emerging new education technology which attempts to fill the need for self-directed learning dan long-life learning.

Keywords: Industrial Revolution 4.0, Education 4.0, Self-Directed Learning, Long-Life Learning, Education Technology

\section{Pendahuluan}

Sepanjang perkembangan ekonomi dan teknologi dunia, telah terjadi 4 kali perubahan signifikan dalam dunia industri. Revolusi industri yang telah berlalu diantaranya adalah: produksi dengan mesin mekanik pada abad ke 18, produksi industri secara masal di akhir abad ke-19, dan kemunculan internet pada tahun 1960an (Hirschi, 2018). Perubahan signifikan kembali terjadi dan dikenal sebagai revolusi industri ke-4. Revolusi industri ke-4 ditandai dengan berkembangnya teknologi maju seperti artificial intelligence, cloud computing, nanotechnology, biotechnology, printer 3 dimensi dan sebagainya.

Perbedaan revolusi industri ke-4 dengan revolusi yang pernah terjadi sebelumnya adalah teknologi yang berkembang saat ini tidak lagi sekedar untuk mendukung manusia dalam bekerja atau mereduksi para pekerja fisik, namun teknologi yang dikembangkan sudah menggantikan pekerjaan kognitif dan fisik sekaligus (Benedikt \& Osborne, 2017). Sepanjang dekade ini, teknologi berkembang sangat pesat. Salah satunya adalah teknologi automasi dan robot yang secara pelan namun pasti menggantikan peran manusia dalam industri (Ford, 2015)

Dinamika perubahan yang cepat seiring dengan munculnya revolusi industri 4.0, berimbas pada dunia pendidikan. Mau tidak mau pendidikan harus terus menyesuaikan dengan perubahan yang terjadi untuk mempersiapkan murid menghadapi dinamika revolusi industri 4.0. Education 4.0 adalah konsep pendidikan yang merespon kemunculan revolusi industri 4.0. Pada artikel ini, akan dibahas kemunculan dan perkembangan Education 4.0.

Adapun beberapa permasalahan yang hendak dibahas dalam artikel ini adalah karakteristik utama konsep Education 4.0, peran pendidik dalam Education 4.0 Metode dan Platform belajar apa saja yang mendukung Education 4.0. 


\section{Metode}

Artikel ini merupakan artikel review perkembangan Education 4.0 hingga saat ini. Metode yang digunakan dalam menyusun review ini adalah analisis konten dari artikel-artikel dan laporan penelitian tentang Education 4.0 yang telah ada.

\section{Pembahasan}

\section{Karakteristik Education 4.0}

Terdapat beberapa pergeseran konsep belajar dalam Education 4.0, diantaranya (Fisk, 2017), yaitu:

1. Diverse time and place (keragaman waktu dan tempat belajar).

Murid memiliki kesempatan belajar pada waktu dan tempat yang bebas. Murid juga dapat mengatur seberapa lama waktu yang ia investasi untuk mempelajari sesuatu. Peserta diidk yang memiliki kemampuan belajar lambat pada materi tertentu, dapat menginvestasikan waktu yang lebih lama untuk mengulang materi atau melakukan latihan-latihan. Sedangkan mereka yang dapat lebih cepat memahami materi dapat segera berpindah ke materi yang lain.

Tempat belajar juga sangat fleksible. Salah satu sarana untuk memfasilitasi kesempatan ini adalah E-learning. Kelas dapat dilakukan dengan konsep flip-classroom atau blended learning. Teori dapat dipelajari menggunakan berbagai macam alat, sumber belajar, teknik, dan program sesuai dengan yang diinginkan oleh murid. sedangkan, praktik dapat dilakukan dengan tatap muka interaktif.

2. Personalized learning (pembelajaran pribadi)

Murid belajar dengan sumber atau media belajar yang sesuai dengan kemampuan dan karakteristik masing-masing. Murid dengan kemampuan di atas rata-rata dapat mempelajari materi lebih mendalam/sulit dengan tugas yang lebih kompleks. Sedangkan murid yang kemampuannya di bawah rata-rata dapat memiliki kesempatan untuk latihan terus-menerus hingga diperoleh level penguasaan yang diinginkan.

Murid memiliki cara belajarnya masing-masing. Dalam proses belajar individu ini, murid akan berusaha melalui caranya untuk dapat menguasai/ memahami materi yang diinginkan dengan menggunakan berbagai macam 
alat bantu. Proses belajar individu akan memberikan penguatan positif kepada murid. meskipun terkadang terdapat berbagai kendala selama proses yang dijalani, murid akan memiliki kepercayaan diri yang lebih terhadap kemampuannya sendiri setelah berhasil melewati proses tersebut.

3. Free choice (pilihan bebas)

Untuk mencapai tempat tujuan tertentu, kita dapat menempuh berbagai macam rute. Hal ini sama dengan pengalaman belajar personal setiap anak. Murid bebas dalam menentukan atau memodifikasi proses belajarnya dengan menggunakan sumber atau alat yang sesuai dengan karakter masing-masing murid.

4. Project based learning (pembelajaran berbasis proyek)

Seperti yang teramati pada fenomena revolusi industri 4.0, pekerjaan atau karir yang dijalani oleh seseorang akan terus berubah sesuai dengan perkembangan industri, ekonomi, dan teknologi. Di masa mendatang, perubahan akan terus terjadi. Peserta diidk yang saat ini belajar harus dapat beradaptasi secara cepat pada pekerjaannya di masa mendatanng.

Project based learning adalah salah satu sarana yang dapat digunakan untuk melatih murid dalam beradaptasi pada dunia kerja yang dinamis di masa depan. Dalam project based learning, murid dilatih untuk menerapkan pengetahuan dan keterampilan yang dimiliki pada berbagai macam situasi tugas. Dalam proses project based learning, murid juga berlatih prinsip organisasi, kolaborasi, dan pengaturan waktu. Keterampilan tersebut akan digunakan seterusnya dalam jenjang akademik maupun karir.

5. Field experience (Pengalaman lapangan)

Teknologi dapat memfasilitasi penguasaan domain pengetahuan yang lebih efektif dan efiesien, misalnya dengan menggunakan teknologi E-learning. Dengan demikian, pemaparan teori melalui tatap muka tidak perlu banyak dilakukan. Di sisi lain, ini memberikan ruang yang dapat memfasilitasi pengembangan keterampilan yang memerlukan interaksi dengan manusia lain. Pengalaman 'lapangan' dapat memperkuat pembelajaran. Sekolah atau lembaga pendidikan menyediakan kesempatan yang lebih luas pada murid untuk memperoleh keterampilan riil yang bisa relevan dengan pekerjaan peserta diidk di masa mendatang. Oleh karena itu, kurikulum perlu dirancang untuk memberikan ruang bagi murid untuk melakukan internship (magang), proyek mentoring, dan proyek kolaborasi. 
6. Data interpretation (Interpretasi Data)

Salah satu literasi yang diperlukan saat ini dan masa mendatang adalah literasi data. Komputer dapat melakukan analisis data dan menggambarkan tren dari sebuah data untuk memprediksi keadaan di masa mendatang. Kemampuan matematis untuk melakukan kalkulasi dan analisis mungkin sudah tidak begitu penting, karena komputer sudah dapat melakukannya. Namun yang lebih penting adalah interpretasi yang dilakukan oleh orang terhadap hasil analisis data tersebut. Pengembangan literasi data akan menjadi salah satu komponen yang tidak dapat ditinggalkan pada kurikulum pembelajaran di masa depan.

7. Perubahan Sistem Ujian (Assessment)

Seiring kemajuan akses terhadap platform belajar yang lebih beragam, system penilaian tradisional dengan menggunakan ujian tertulis untuk mengukur kompetensi akan semakin tidak relevan. Ujian dinilai sudah tidak valid untuk menilai bahwa murid sudah berkompetensi. Ujian juga tidak dapat menentukan kesiapan seseorang dalam memasuki dunia kerja. Pengetahuan faktual yang dimiliki oleh murid data diukur selama proses belajar, dan aplikasi dari pengetahuan yang diperoleh dapat diuji melalui pekerjaan mereka pada sebuah proyek.

8. Student ownership to curricula (Kurikulum juga dimiliki murid)

Murid akan menjadi lebih terlibat dalam menyusun kurikulum belajarnya. Kurikulum yang kontemporer, up-to-date dan bermanfaat dapat terwujud jika ada keterlibatan dari professional pendidikan dan para murid itu sendiri.

9. Pentingnya Program Mentoring

Dalam pendidikan, murid dilatih untuk mandiri dalam belajar. Selama proses tersebut, peran pendidik professional sebagai mentor sangatlah signifikan. Pendidik memiliki peran sentral untuk membantu murid memilih bahan belajar dari sekian banyak sumber informasi yang ada. Pendidik juga memberikan bimbingan pada murid bagaimana caranya mengeksplorasi diri dengan berbagai macam pengalaman yang dapat meningkatkan kapabilitas peserta didik sehingga menjadi lebih optimal. Walaupun platform belajar digital ke depan akan semakin tersedia dan diminati, peran guru dan institusi akademik tetap penting pada pendidikan seseorang. 


\section{Pendidik pada Education 4.0}

Keterampilan yang harus dimiliki para pendidik untuk menghadapi Revolusi Industri 4.0 adalah (Lase, 2019):

1. Akrab dengan Teknologi

Dunia terus beruah dan berkembang. Teknologi pun terus berkembang hingga banyak hal yang dulunya hanya dapat dilakukan manusia, saat ini dapat dilakukan dengan alat saja. Tidak ada cara lain untuk menghadapi tentangan perkembangan teknologi, selain kemauan untuk belajar secara terus-menerus. Pendidik harus meng-upgrade pengetahuan dan keterampilan dalam menggunakan teknologi. Perubahan yang sangat dinamis tidak perlu dianggap sebagai sesuatu yang mengancam, namun perlu dihadapi secara positif dengan belajar, beradaptasi, dan bekerjasama dengan kolega.

2. Kolaborasi

Kolaborasi antar pendidik sangat diperlukan untuk merancang kurikulum pembelajaran Education 4.0. Dinamika perubahan yang sangat dinamis di dunia membuat kurikulum belajar harus terus-menerus diupgrade. Sharing pengalaman dan pengetahuan antar pendidik akan memperkaya konten kurikulum dan inovasi pendidikan lainnya.

3. Sikap kreatif dan mau mengambil resiko.

Kreativitas adalah salah satu skill yang diperlukan oleh murid di abad ke-21. Namun demikian, untuk mengembangkan kreativitas pada peserta didik, pendidik juga harus kreatif. Kreativitas dibutuhkan oleh pendidik untuk menghasilkan konten kurikulum, pendekatan, atau metode pembelajaran inovatif yang dapat menjadi solusi penyelesaian masalah riil di lapangan. Guru tidak perlu terlalu takut untuk melakukan kesalahan atau gagal dalam menerapkan inovasinya dalam pembelajaran. Kekurangan pada inovasi adalah bahan yang dapat menjadi evaluasi perbaikan nantinya.

4. Guru harus mampu mendidik secara holistik

Untuk membantu murid mengembangkan pengetahuan, keterampilan sikap, emosi, dan nilai yang bermakna, mendalam, dan awet, guru perlu menggunakan pendekatan holistik. Pendekatan holistik didefinisikan sebagai pendekatan pegagogik yang berusaha untuk (a) mendukung murid untuk belajar dan tumbuh pada segala aspek, kognitif, afektif, dan psikomotor, (b) menyertakan berbagai metode pendidikan yang merangsang murid untuk bereksplorasi secara personal dan membantu 
perserta didik untuk menghubungkan apa yang dipelajari dengan konteks kehidupan sehari-hari, (c) membantu murid untuk menemukan nilainilai hidup mereka dan menumbuhkan tanggungjawab pada sesama dan masyarakat (Grauerholz, 2010).

Pendekatan holistik dalam pendidikan dapat mendorong murid untuk belajar secara mendalam. Hal ini disebabkan oleh beberapa hal, diantaranya:

Dalam pendekatan holistik, guru harus mengenali aspek emosi, moral, spiritualitas, intelektualitas, dan hambatan belajar setiap murid. Guru juga perlu melibatkan emosi, moral, dan spiritualitas dalam pembelajaran. Guru yang holistik memandang kelas terdiri dari murid dengan multi karakter. Murid berasal dari latar belakang yang sangat beragam, intelegensi yang bervariasi, dan sifat yang bermacam-macam. Semuanya itu terintegrasi dalam sebuah proses pembelajaran. Mengenali setiap latar-belakang dan karaketristik murid penting untuk menyusun bahan ajar yang relevan dan menarik murid untuk belajar lebih mendalam.

Ketimbang menjadi seorang ahli (expert), guru lebih berperan sebagai fasilitator yang memastikan muridnya mendapatkan pengalaman belajar. Selain itu, pendidik holistik harus mampu mengajar secara profesional, memisahkan tugasnya dengan hidup pribadinya (Friedrichs, 1987). Pendidik yang holistik juga memberikan ruang yang nyaman bagi peserta didik untuk menyampaikan gagasan dan perasaannya secara terbuka. Suara dan pengalaman dari murid dapat menjadi bahan perbaikan konten kurikulum dan metode mengajar. Guru yang holistik juga harus membantu murid untuk berpikir kritis melalui pertanyaan, penyampaian masalah, dan berbagai kegiatan belajar lainnya.

\section{Inovasi Teknologi Pembelajaran pada Education 4.0}

Menurut Dunwill (Hussin, 2018) akan terdapat banyak perubahan tampilan kelas untuk menghadapi revolusi industri 4.0. Perubahan tersebut meliputi adanya tugas-tugas yang fleksibel untuk murid guna mengakomodasi berbagai macam gaya belajar. MOOC (massive open online course) akan terus berkembang dan disertakan dalam pembelajaran di sekolah maupun universitas. Teknologi pembelajaran seperti virtual dan augmented reallity akan semakin banyak digunakan untuk mendukung efektifitas pembelajaran. 


\section{Blended Learning}

Pada pendidikan formal, baik menengah maupun tinggi, blended learning dapat digunakan sebagai metode pembelajaran pada Education 4.0. Blended learning menggabungkan Elearning dan tatap muka. Blended learning dinilai lebih efektif ketimbang murni tatap muka atau Elearning saja (Garrison \& Kanuka, 2004).

Pada blended learning, materi yang bersifat teoritis dapat diberikan melalui platform belajar online atau E-learning. Tatap muka tetap diperlukan untuk mendiskusikan pesoalan yang ada selama belajar secara online. Kelas tatap muka tidak perlu banyak membahas tentang teori tetapi murid diarahkan untuk mendapatkan pengalaman langsung, seperti misalnya praktek atau eksperimen.

Untuk menyediakan materi Elearning yang sesuai dengan kurikulum yang disusun, guru dapat memanfaatkan open education resources yang sudah tersedia, atau pun merancang materi online course sendiri.

Jika ingin menyusun online course sendiri, institusi dapat membuat website E-learning sendiri atau dapat memanfaatkan platform yang tersedia gratis seperti Google Classroom, Schoology. Schoology memberikan fasilitas seperti ruang pembuatan materi yang dapat dimodifikasi, link ke materi di luar, ruang komunikasi guru dan murid, ruang diskusi kelas, fitur untuk mengupload proyek, dan fitur evaluasi. Pendekatan inovatif dan fitur pada Schoology memfasilitasi guru, murid, dan orang tua untuk membangun komunitas kolaboratif belajar untuk memenuhi tujuan pendidikan pada Abad ke 21 . Schoology juga diharapkan dapat menjadi sarana penghubung dan kolaborasi antar stakeholder pendidikan (Biswas, 2013).

\section{Open Education Resources}

Open Education Resources telah menjadi salah satu platform belajar online yang dapat diakses oleh banyak orang untuk sumber belajar. Open Education Resources ini ada yang sifatnya sebagai bagian dari pendidikan formal dan disediakan oleh sebuah lembaga pendidikan formal, misalnya universitas. Salah satu universitas yang sudah lama memperkenalkan open education resources adalah MIT (Massachusetts Institute of Technology) dengan MIT Open Course Ware (OCW) (https://ocw.mit.edu/index.htm) yang diluncurkan sejak musim semi 2001.

Awalnya, MIT Open Course Ware ini adalah adalah menjadi sarana berbagi bagi komunitas lokal. Pada lingkungan kampus tradisional, tidak banyak profesor 
yang berkesempatan untuk saling berbagi silabus dan materi perkuliahan. Jarang juga mereka melakukan diskusi tentang metode pembelajaran. Namun dengan adanya MIT Open Course Ware ini, profesor yang mengajar di MIT pun bisa melihat silabus, materi, dan metode yang diberikan oleh profesor lain dengan mudah. Dampak dari kemudahan akses ini adalah profesor dapat melakukan refleksi diri pada pebelajran yang dia lakukan, dapat mencari referensi metode pembelajaran yang lebih efektif dari profesor lain, dan dapat mengkorelasikan materi ajarnya dengan mata kuliah lain terkait.

Saat ini, MIT Open Course Ware telah digunakan oleh komunitas yang lebih luas. Bahkan materi telah diterjemahkan ke beberapa bahasa selain Bahasa Inggris supaya dapat dipakai secara lebih luas. MIT adalah universitas yang mempelopori proyek kuliah online terbuka yang dapat diakses oleh setiap orang di berbagai negara. Open education resource tidak mengikat secara institusional. Setiap orang dapat belajar tanpa adanya ikatan administrasi dan ijasah.

Proyek Open Education Resources telah berkembang pesat. Banyak universitas yang lain yang mengikuti langkah MIT. Rice University juga telah mengembangkan open education resources yang diberi nama Connextion. Pada tahun 2005, Utah State University juga meluncurkan USU OCW. Beberapa universitas besar di Jepang yaitu Keio University, Kyoto University, Osaka University, Tokyo Institute of Technology, University of Tokyo, dan Waseda University berkolaborasi untuk membuat Japan OCW Collaboration Group pada 13 Mei 2015 (Johnstone, 2005).

Revolusi industri 4.0 juga telah sedikit menggeser pandangan tentang pentingnya pendidikan tinggi formal dan lisensi/ijasah. Seperti diketahui saat ini, beberapa perusahaan seperti Google dan Facebook telah mendeklarasikan bahwa mereka tidak lagi merekrut talenta-talenta muda berdasarkan ijasah universitas yang dimilikinya, namun berdasarkan kompetensi dan pengalaman yang dimiliki (Connley, 2018). Hal ini berimbas pada semakin banyaknya online course yang menjadi platform belajar informal yang lebih fleksibel bagi murid. setiap murid dapat melakukan pengembangan diri dengan belajar hal yang diinginkan secara individual dengan menggunakan bantuan platform belajar online.

\section{Knowledge Sharing Economy (KSE)}

Kebutuhan akan self-directed learning (pembelajaran individual) untuk pengembangan diri bahkan telah dipandang sebagai kesempatan bisnis. 
Beberapa perusahaan menyediakan platform berbayar untuk saling membagikan pengetahuan. Layanan berbayar yang menyediakan jaringan sosial online untuk berbagi pengetahuan, pengalaman, dan keterampilan dikenal sebagai knowledge sharing economy (KSE) (Zhang, Jiang, Xiao, \& Cheng, 2018).

Adanya pandangan akan pentingnya untuk mengembangkan diri seluasluasnya tanpa adanya batasan terhadap gelar, juga telah menarik orang untuk menggunakan platform KSE walaupun mereka perlu mengeluarkan uang. Uang yang dikeluarkan ini dapat dipandang sebagai investasi layaknya apabila orang mengeluarkan uang untuk menempuh pendidikan di universitas. Konsep "Paying for knowledge" perlahan tapi pasti dapat diterima oleh para konsumen. Di China, transaksi KSE telah mengalami pertumbuhan 205\% pada tahun 2017 (SIC, 2017)

Beberapa vendor yang menyediakan adalah Quora Knowledge Prize, Udemy, dan SkillShrae yang berasal dari Amerika Serikat. Udemy menawarkan kelas online yang terdiri dari berbagai bidang seperti IT, software, ilmu sosial matematika, sains, teknik, markering, musik, dan sebagianya. Udemy juga merupakan platform berbayar dimana setiap murid perlu membayar setiap course yang diaksesnya (Udemy, 2020)

Skill Share mengusung konsep learning by doing, learning with other, learning for the future. Saat ini terdapat banyak video materi belajar dari berbagai bidang, akan tetapi masih didominasi oleh materi tentang desain, media, komputasi, dan marketing (SkillShare, 2020)

Salah satu fitur yang ditawarkan oleh Skill Share adalah Share project, setelah menyelesaikan kegiatan pembelajaran, pembelajar dapat mengupload project yang mereka buat, dibagikan ke komunitas, dan mendapatkan penilaian untuk perbaikan dari komunitas belajar yang diikuti.

KSE memanfaatkan kebutuhan akan long life learning. Orang-orang yang telah bekerja dapat melakukan pengembangan diri dan upgrading kompetensi dengan mengikuti course yang ada pada KSE. KSE bahkan menyediakan ilmuilmu baru seperti Data Science yang belum tentu mudah ditemukan dalam pendidikan formal. KSE dapat menyediakan berbagai course yang up-to-date karena platform ini bekerjasama dengan para professional yang bekerja pada bidang masing-masing untuk membagikan pengalaman mereka dengan menjadi instructor. KSE mungkin tidak memiliki guru bersertifikat sebagai pengajar, namun mereka menawarkan platform yang mempertemukan orang yang ingin mensharingkan pengetahuannya dengan orang yang ingin belajar secara online. 
Keuntungan dari biaya yang dibayarkan oleh pengguna digunakan dibagi kepada para instructor yang bergabung.

Di Indonesia sendiri, meskipun belum banyak jumlahnya. Beberapa platform KSE sudah mulai bermunculan, seperti Quipper dan Ruang Guru. Akan tetapi, platform ini kebanyakan masih menyediakan konten yang berkaitan dengan materi ajar di sekolah menengah saja.

\section{Kesimpulan}

Era revolusi industry 4.0 telah memunculkan pergeseran konsep pendidikan ke arah Education 4.0. Education 4.0 sendiri memiliki karakteristik adanya keterbukaan dan kemerdekaan dalam belajar, tuntutan konsep selfdirected learning, dan long-life learning. Meskipun Education 4.0 berpusat pada peserta didik, peranan guru pada pendidikan menengah tetap masih penting. Guru di sekolah menengah berperan sebagai fasilitator yang membimbing peserta didik untuk dapat mengenali minatnya dan belajar secara mandiri.

Sumber belajar pada era Education 4.0 sangat luas dan tidak terbatas pada materi ajar di kelas. Pendidikan informal dengan menggunakan platform online juga banyak bermunculan untuk memfasilitasi konsep self-directed dan long-life learning.

\section{Daftar Pustaka}

Benedikt, C., \& Osborne, M. A. (2017). Technological Forecasting \& Social Change The future of employment: How susceptible are jobs to computerisation? [. Technological Forecasting $\mathcal{E}$ Social Change, 114, 254280. https://doi.org/10.1016/j.techfore.2016.08.019

Biswas, S. (2013). Schoology-Supported Classroom Management : A Curriculum Review. Northwest Journal of Teacher Education, 11(2), 187-196. https:// doi.org/10.15760/nwjte.2013.11.2.12

Connley, C. (2018). Google, Apple and 12 other companies that no longer require employees to have a college degree. Retrieved from https://www. cnbc.com/2018/08/16/15-companies-that-no-longer-require-employeesto-have-a-college-degree.html

Fisk, P. (2017). Education 4.0. Retrieved from https://www.thegeniusworks. com/2017/01/future-education-young-everyone-taught-together/

Ford, M. (2015). Rise of the robots: Technology and the threat of a jobless future. New 
Humanika, Kajian IImiah Mata Kuliah Umum, Vol. 20. No. 1. (2020), 1-12

Yokr: Basic Books.

Garrison, D. R., \& Kanuka, H. (2004). Blended learning: Uncovering its transformative potential in higher education. Internet and Higher Education, 7, 95-105. https://doi.org/10.1016/j.iheduc.2004.02.001

Grauerholz, L. (2010). Teaching Holistically to Achieve Deep Learning. College Teaching, 49, 44-50. https://doi.org/10.1080/87567550109595845

Hirschi, A. (2018). The Fourth Industrial Revolution : Issues and Implications for Career Research and Practice. The Career Development Quarterly, 66, 192-204. https://doi.org/10.1002/cdq.12142

Hussin, A. A. (2018). Education 4 . 0 Made Simple: Ideas For Teaching. International Journal of Education and Literacy Studies, 6(3), 92-98.

Johnstone, S. M. (2005). Open Educational Resources Serve the World. Education Quarterly, 3, 15-18.

Lase, D. (2019). Education and Industrial Revolution 4.0. Jurnal Handayani, 10(1), 48-62.

SIC. (2017). The development of Chinese sharing economy in 2017. Retrieved from http://www.sic.gov.cn/\%OAarchiver/SIC/UpFile/Files/ Htmleditor/201703/2017002 125144221.pdf

SkillShare. (2020). Skill Share. Retrieved January 1, 2020, from https://www. skillshare.com/about

Udemy. (2020). Udemy. Retrieved January 1, 2020, from https://www.udemy. $\mathrm{com} /$

Zhang, X., Jiang, S., Xiao, Y., \& Cheng, Y. (2018). Global challenges and developmental lessons in the knowledge sharing economy. Journal of Global Information Technology Management, 21(3), 167-171. https://doi.or g/10.1080/1097198X.2018.1505071 